\title{
Panglima Laot: Maritime Cultural Heritage and Sustainability of the Coastal Environment in Aceh
}

\author{
Mujiburrahman $^{1 *}$, Yety Rochwulaningsih ${ }^{2}$, Singgih Tri Sulistiyono ${ }^{2}$, and Mahendra Pudji \\ Utama $^{1}$ \\ ${ }^{1}$ Doctoral Program, Faculty of Humanities, Diponegoro University, Semarang, Indonesia. \\ ${ }^{2}$ Departement of History, Faculty of Humanities, Diponegoro University, Semarang, Indonesia.
}

\begin{abstract}
This paper examines the damage to the marine and coastal environment in Aceh. This happens because human behavior does not care about environmental safety in exploring marine resources. However, on the coast of Aceh there is one wisdom value that can limit human behavior, namely Panglima Laot. Panglima Laot is a maritime cultural heritage from the Kingdom of Aceh to the republic. Panglima Laot is the result of the adaptation of the structure of the Kingdom of Aceh into the structure of coastal culture in Aceh. This coastal wisdom is a major asset as a social infrastructure in limiting human behavior to ensure environmental sustainability. The research method used in observing this maritime social phenomenon is a qualitative method with sociological and anthropological approaches. The results showed that Panglima Laot has a social system that promotes environmental sustainability. This system is able to limit human behavior in exploring the natural resources of the coast and the sea. In general, the social system owned by Panglima Laot is divided into three, namely hukom adat laot, adat laot and hukom meupayang. This is a significant value in limiting human behavior for the sake of the sustainability of the coastal environment.
\end{abstract}

\section{Introduction}

Panglima Laot is a maritime cultural heritage of the Aceh Kingdom, which is based on Aceh Qanun No. 10 of 2008 concerning on Customary Institutions have become local wisdom. Panglima Laot had existed since the days of Samudra Pasai Kingdom in the 14th century, then it was confirmed by Sultan Iskandar Muda (1607-1636). At that time, Panglima Laot was an extension of the sultan's hand to carry out two main tasks, namely collecting excise from merchant ships anchored at the port and mobilizing the people for war purposes [1]. By A.M. Djuliati Suroyo, Aceh at Sultan Iskandar Muda had issued a customary sea law, which specifically regulated fishing in the sea, related to fishers, wages for work, boats, equipment and others. The official who takes care of all of this is Panglima Laot. The arguments mentioned above prove that Panglima Laot has been running for a long time in the life of

* Corresponding author: mujiburrahmanmuji@gmail.com 
Acehnese fishers [2]. Local wisdom of traditional institutions of Panglima Laot is a maritime cultural heritage of Indonesia. It is one of the rich cultural characteristics of the Indonesian nation as a maritime country.

This tradition that upholds the preservation of marine and coastal areas is a form of wisdom that is the spirit of the customary institution of Panglima Laot. In a society that still upholds its local wisdom, respect for nature is something significant. In this society, there are several principles and patterns of behaviour that should be found. According to Sony Keraf, ethical principles in the environment must be considered: respect for nature, moral responsibility for nature, cosmic solidarity, compassion, and care for nature. Human has moral responsibilities and obligations towards nature, with environmentally friendly behaviour, living simply and in harmony with nature, and justice [3].

Referring to the fisheries monograph of the Special Region of Aceh [4], there are at least four primary duties of Panglima Laot. The duties are as follows: 1). Oversee and maintain customary maritime laws; 2) Regulate fishing procedures; 3) Resolve various disputes that occur in connection with fishing in the sea; 4) Organize traditional maritime ceremonies, handle accidents at sea, cooperation and other social problems.

In the handbook of Teungku Imum Menasah custom, it is stated that Panglima Laot is a person who leads the customs or habits that apply in the field of fishing in the sea. Besides, this institution is also tasked to regulate fishing places/areas, boat mooring and resolve the production sharing disputes. The power of Panglima Laot merely applies in the marine area, covering all aspects of life in the sea. Panglima Laot's duty is not only to make arrangements but also to provide sanctions [5].

In the era of technological advances nowadays, it leads to human greed being unstoppable. It is included in exploring the natural wealth of the sea. Human in digging the natural wealth of the sea is no longer considered environmental sustainability to ensure the sustainability of the environment itself. Many fishing equipments is not environmentally friendly, and some even use bombs and trawlers to increase catch without paying attention to environmental damage. However, indigenous fishing groups still have values that are very respectful of the environment. Even though in the current era of progress, traditional values are also being eroded. However, the existence of traditional nelaan led by the Panglima Laot still exists. This coastal cultural heritage is quite effective in limiting human behaviour to damage the marine coastal environment. Therefore, this paper will discuss how Panglima Laot limits fishermen's behaviour with customary corridors in ensuring the sustainability of the coastal environment.

\section{Method}

The research method used in this research was a qualitative research method with historical and anthropological research approaches. A historical approach was needed to analyze and understand Panglima Laot as a legacy of the Aceh kingdom. Meanwhile, the anthropological approach is to understand Panglima Laot as a local and coastal culture in Aceh. In general, data analysis refers to the principle of caution and high data trust. According to Moleong, there are four types of data validity criteria, namely (1). Credibility (2) transferability (3) dependability (4) Confirmability. In this qualitative research, to test the validity of the data that has been obtained, it will be oriented to 2 criteria as the standard of analysis, namely trust (credibility) and certainty (confirmability) [6]. The primary sources in this research were archives, interviews, books, and journals credible to the research. 


\section{Results and Discussion}

Panglima Laot, as local wisdom, has a customary corridor to demand community behaviour in respecting nature. For fishers who uphold traditional values, they admit that the nature of the media attracts sustenance. Thus it is only natural for fishers to respect nature.

\subsection{Local Wisdom}

Wisdom is a necessity that is embedded in a society that upholds respect for nature. Each region has its local wisdom, every community must have a different culture, so this is one of its cultural diversity. According to Melville J Herkovits and Bronislow Malonowski, everything in society is determined by the existence of the culture owned by the community [7]. This opinion has been reinforced by Soerjono Soekanto, who argues that society means people who live together who produce culture. Thus, no society does not have culture and vice versa; there is no culture without society as a frame of the cultural portrait. [8]

In a society that still upholds its local wisdom, respect for nature is something significant. In this society, there are several principles and patterns of behaviour that should be found. Based on Sony Keraf, the ethical principles in the environment must be considered: respect for nature, moral responsibility for nature, cosmic solidarity, compassion, and care for nature. Humans have moral responsibilities and obligations towards nature, with behaviour favouring the environment, living simply and in harmony with nature, and justice [3]. One of the local wisdom in Aceh is Panglima laot. This is coastal wisdom that has developed since the days of the kingdom [7].

\subsection{Panglima Laot and The Kingdom of Aceh}

Panglima Panglima Laot has existed since the days of Samudra Pasai Kingdom in the 14th century, then confirmed by Sultan Iskandar Muda (1607-1636). At that time, Panglima Laot extended the Sultan's hand to carry out two main tasks, namely collecting excise from merchant ships anchored at the port and mobilizing the people for war purposes [1]. This opinion is the argument that the Panglima Laothas been running for a very long time in the life of the people of Aceh. Panglima Laot is part of the government during the kingdom. Van Volenhoven asserted that "There are many different kinds of authorized institutions in Aceh. Besides the head, we can find a brother called as a banta or assistant, more or less so, before 1900. There is ahead of mukim, and a system of government divided into four and waki or deputies in independent institutions. At the port, which is the centre of relations for all civilizations and wealth throughout the Malay state, there is a syahbandar (quoter of entry and exit fee). In Kuala, there is a Krueng chief to guard the wide-open waters, and a Krueng handler to maintain the ferry service from which the head shares remuneration; in markets around the east coast, Haria collects taxes, and Panglima Laot for export and import duties; Panglima Prang collects wase and taxes in peacetime" [3].

The main job of Panglima Laot at that time was to monitor activity in the ports, utterly unrelated to monitoring fishers. Panglima Laot is an essential instrument at the port that works under the control of the harbormaster [3].

According to Muhammad Said, adat laot is controlled by the Panglima Laot in collaboration with ule balang or kedjrun Kuala as government staff [9]. According to Kamaruzzaman, the Panglima Laot is the guardian of the laot customary law and as part of the government. Panglima Laot collaborates with Syah Bandar and Ulee Balang in coastal areas. During the Islamic Kingdom era in Aceh, all customary institutions, including the Panglima Laot, were united in a government system under the control of the Sultan [3]. Ibrahim Alfian said that, when the Aceh war with the Dutch was raging, Tuanku Muhamad 
Syah served as Sultan had selected several people to fight against the Dutch. Tengku Chik Di Tiro as qadhi malikul fair, and Teuku Umar as amir al-bahri or Panglima Laot in West Aceh [10]. This condition shows that the Panglima Laot is part of maritime security in Aceh, which is controlled by the kingdom. It should also be added that the position of ulee balang and Sultan has disappeared since the war between Aceh and the Netherlands (1873-1942) [10]. Because there was no ule balang institution during the independence era, the Panglima Laot did not work with ule balang, which did not have the authority as a customary institution [10]. In other words, Panglima Laot became a 'cultural heritage of the Islamic Kingdom in Aceh, which initially had a strategic function in coastal areas [7].

\subsection{Laot Custom and and Laot Customary Law}

According to Mujiburrahman, the Panglima Laot has a significant role in the fishing community; the Panglima Laot plays at least four roles. All four roles include 1). The Role of Panglima Laot in Carrying Out Laot Custom; 2). The Role of Panglima Laot in Implementing Laot Customary Law; 3). The Role of Panglima Laot in Carrying Out Meupayang Law; 4). The Role of Panglima Laot in Resolving Customary Disputes.

The four aspects of this role constitute the hereditary strategic role of the Panglima Laot in realizing environmental sustainability. Customary law is needed to limit behaviour; in this casem, the behaviour of fishers is directly related to the sea. As is well known, the damage to the marine environment is greatly influenced by human behaviour that does not respect nature. On the other hand, customary law also fills in the void of positive law. It can be seen that customary law still applies in people's lives. Soerjono said there are four reasons why the phenomenon of customary law continues, namely 1). Customary law must exist; the written law will not proportionally regulate all the community's interests and its citizens; 2). In a society experiencing relatively fast but directed social change, the role of customary law is more prominent than written law; 3 ). In a pluralistic culture such as our country, Indonesia, unique cultures (Sub Culture) cannot be ignored in the life of the nation and state; 4). The patterns in customary law can be used to institutionalize written law [1].

Laot custom is an essential aspect in ensuring the sustainability of the coastal environment. The laot custom itself consists of several parts. The first part is the Khanduri Laot Custom; the Khanduri laot ceremony before the eastern season or when the west season ends. [11]. Khanduri laot for the Acehnese fishing community is the form of the relationship between humans as creatures and their creators and the surrounding environment in dealing with the local environment [12]. Khanduri laot is an evaluation momentum in the implementation of custom and a place to reaffirm customary law. Another part of the khanduri laot is social customs and customs to protect the environment. In this custom, fishers help each other and are prohibited from cutting down trees and using tools that damage the coastal environment. This includes such as do not catch the riveted animals of turtles and dolphins. The last is the custom of drifting goods, wherein this custom every drifting good must be submitted to the Panglima Laot.

Another aspect of protecting the Panglima Laot environment has a role in the customary law of laot, also known as abstinence. The laot customary law is taboo laot on predetermined days. Several days have been set out to go to sea in Aceh's customary law of the sea. First, there is no fishing for fishers for one day, from sunset on Thursday until sunset on Friday. Second, abstinence from going to sea for three days after three days of khanduri laot, calculated from the time the sun goes out of khanduri laot until the sun sets on the third day. Third, abstinence from going to sea on Eid al-Fitr. This prohibition is valid for three days from when the sun sets on the holding day until the sun sets on the second day of Eid. Fourth, abstinence from going to sea on Eid al-Adha for three days, counting from sunset on the day of holding until sunset on the third day of Eid al-Adha. Fifth, abstinence from going to sea 
on the day of independence on August 17, 1945, starting from the sunset on August 16 to the sun's setting on August 17. Since the earthquake and tsunami hit Aceh on December 26, 2004, which claimed many victims, the Panglima Laot also banned fishing on December 26, starting from the sunset on December 25 until the sun on December 26.

With the enactment of no-sea days, it will have a positive impact on fishers and have a good impact on the sustainability of the marine and coastal environment for the future. Abstinence from laot is a concrete form of protecting the environment. This value is accumulated from all the days of abstinence which the Panglima Laot carries out through the traditional law of laot. With the fishermen's holidays, fish and marine life can have the opportunity to develop so that nature can also be preserved with fishermen holidays. The existence of this laot abstinence has indirectly allowed the fish to breed correctly.

Table 1. Result

\begin{tabular}{|c|c|c|}
\hline No & Daya Name & Total Days \\
\hline 1 & Khanduri Laot & 3 \\
\hline 2 & Every Friday. 1 day x 48 times in one year & 48 \\
\hline 3 & Eid Al Fitr Day & 3 \\
\hline 4 & Eid Al Adha Day & 3 \\
\hline 5 & Every 17 of August & 1 \\
\hline \multirow[t]{2}{*}{6} & Every 26 of December & 1 \\
\hline & Total & 59 \\
\hline
\end{tabular}

Abstinence laot is the value of wisdom that is very friendly to the sea itself. This wisdom value has become fundamental in dealing with nature through the values or norms of laot custom and the law of laot custom [13]. This wisdom value is a maritime cultural heritage from the Aceh kingdom, which has become a treasure of coastal culture in Aceh [14]. The aspect of custom has become an essential strategy for Panglima Laot in ensuring the sustainability of the coastal environment [15]. Through the traditional values inherited by the Aceh kingdom, the Panglima Laot has a vital role in realizing the preservation of the coastal environment [16]. The existence of laot custom is a concrete action of the Panglima Laot in preserving the environment, especially in protecting the environment. On another aspect, there is abstinence from the sea or laot customary law. Abstinence from the sea has provided a balance to the environment. Nature is allowed to improve itself, at least in one year through the customary law of laot fishers; it has allowed nature to rest for 59 days.

Fisher who violates the sea avoidance day will be punished by confiscating the fish catch and are not allowed to go for sailing at least 3 (three) days until 7 (seven) days [17]. All decisions related to the customary violations will be decided through the local courthouse. Panglima Laot, as the leader of the unit who regulated the fishers and pointed as Lhok, carries out the process of settlement customary disputes that happened among fishers. It can be stated that the Panglima Laot unit actively carries out the judicial process in Hukom Adat Laot.[18].

\section{Conclusion}

Panglima Laot is a maritime cultural heritage of the Aceh kingdom. Nowadays, the royal legacy of Aceh has become coastal wisdom in Aceh. This coastal wisdom has played a significant role in ensuring environmental sustainability. Panglima Laot, through laot custom and laot customary law has had a significant influence on limiting human behaviour towards nature. The customary law of laot and laot custom has placed nature as a median that must be respected. In this way, the Panglima Laot has made a significant contribution to the sustainability of the coastal environment in Aceh. 


\section{Acknowledgment}

This article is funded by Directorate DRPM DIKTI 2019 under the research Doctoral Dissertation Program entitled Penetrasi kolonial dan adaptasi lokal: Perkembangan aktifitas kemaritiman Aceh pada pergantian abad XX.

\section{References}

[1] M. A. Abdullah, Selama kearifan adalah kekayaan: Eksitensi Panglima Laot di Aceh, Banda Aceh: Lembaga Hukom Adat Laot Aceh dan Yayasan KEHATI, 2006.

[2] A. S. Djuliati, Sejarah Maritim Indonesia 1, Semarang: Jeda, 2007.

[3] K. Bustamam Ahmad, Kearifan Lokal di Laut Aceh, Banda Aceh: Center Study of Sea Customery law and Fisheries Policy Syiah Kuala University and Syiah Kuala University Press., 2010.

[4] Anonim, Monografi perikanan Daerah Istimewa Aceh, Banda Aceh: : Dinas Perikanan Aceh., 1973 .

[5] M. S. Suhaidy, Buku Pegangan Teungku Imeum Meunasah, Banda Aceh: Dinas Syari'at Islam Provinsi NAD., 2007.

[6] L. J. Moelong, Metode Penelitian Kualitatif, Bandung: Remaja Rosda Karya., 1991.

[7] Mujiburrahman, "“Perkembangan Panglima Laôt Dan Peranannya Dalam Kehidupan Masyarakat Nelayan Di Kecamatan Kembang Tanjong Kabupaten Pidie, Provinsi Aceh (1990-2007)"," Tesis Pada Jurusan Ilmu Sejarah Pasca Sarjana Universitas Diponegoro, Semarang, Semarang, 2015.

[8] S. Soekanto, Sosiologi Suatu Pengantar, Jakarta: Rajawali Pers, 1987.

[9] H. Zainuddin, Tarich Atjeh dan Nusantara, Medan: Pustaka Iskandar Muda., 1961.

[10] I. Alfian, Perang Di Jalan Allah, Perang Aceh 1873-1912, Yogyakarta, 2016.

[11] Agus Budi Wibowo, Sistem Pengetahuan Kenelayanan Pada Masyarakat Nelayan Aceh Besar, Banda Aceh: Balai Kajian Sejarah dan Nilai Tradisonal, 2000.

[12] A. Suryo, Seri Informasi Budaya, Kenduri Laot Pada Masyakat Aceh, Banda Aceh: Balai Kajian Sejarah dan Nilai Tradisonal., 2008.

[13] M. Rachmad Munazir, "Strategi Lembaga Adat Panglima Laot dalam Menyelesaikan Konflik (Sengketa) Masyarakat Nelayan di Kabupaten Pidie Provinsi Aceh," Jurnal Humaniora, vol. 2, no. 2, pp. 110-117, 2018.

[14] Y. R. Singgih Tri Sulistiyono and Mujiburrahman Mahendra Pudji Utama*, "Transformation of Panglima Laot in Aceh: From Punggawa to Customary Institution," in The 5th International Conference on Energy, Environmental and Information System (ICENIS 2020) Article Number 07031, Semarang, 2020.

[15] Z. Y. M. M. N. Rahcmad Munazir, "MENJAGA KELESTARIAN LINGKUNGAN MARITIM PESISIR YANG BERKELANJUTAN DI KABUPATEN PIDIE DENGAN PENDEKATAN ADAT LAOT," Jurnal Humaniora, vol. 1, no. 2, pp. 7178, 2017. 
[16] E. S. Sutejo K Widodo, "The Development and Roles of Panglima Laot in the Fishermen Community at Pidie, 1990-2007," Advanced Science Letters, vol. 23, no. 10, pp. 10005-10007, 2017.

[17] M. Puspita, "KEARIFAN LOKAL DALAM PENGELOLAAN SUMBER DAYA PESISIR DAN LAUT Hukum Adat Laot dan Lembaga Panglima Laot di Nanggroe Aceh Darussalam," Sabda, Jurnal kajian budaya, vol. 3, no. 2, p. 15, 2017.

[18] S. W. Rahayu, "Lembaga Penyelesaian Sengketa Adat Laut "Panglima Laôt" di Aceh sebagai Bentuk Pengembangan Alternatif Penyelesaian Sengketa dalam Sistem Hukum di Indonesia," Padjadjaran Jurnal Ilmu Hukum, vol. 1, no. 3, p. 456, 2014. 